\title{
Factors Related to Retention Behaviour of Teachers in Islamic Private Schools in Three Southernmost Provinces in Thailand
}

\author{
Chidchanok Churngchow ${ }^{1} \&$ Ruthaychonnee Sittichai $^{2}$ \\ ${ }^{1}$ Faculty of Education, Prince of Songkla University, Pattani, Thailand \\ ${ }^{2}$ Faculty of Humanities and Social Sciences, Prince of Songkla University, Pattani, Thailand \\ Correspondence: Chidchanok Churngchow, Faculty of Education, Prince of Songkla University, Muang, \\ Pattani, 94000 Thailand. Tel: 66-89-975-1766. E-mail: chidchanok.ccce@gmail.com
}

\author{
Received: January 9, 2014 Accepted: March 18, 2014 Online Published: April 29, 2014 \\ doi:10.5539/ass.v10n10p50 URL: http://dx.doi.org/10.5539/ass.v10n10p50
}

\begin{abstract}
This research aimed to study the factors that affect the persistence of ordinary teachers in private schools in three southernmost provinces of Thailand. The samples were 246 ordinary teachers in Islamic private schools divided into 2 categories: the first group was 131 teachers who remained an instructor in the school and the second group was 115 ex-teachers who had resigned from school. This was a mixed method research, using questionnaire and semi-structured interview. Discriminant analysis was employed for data analysis. It was found that only one discriminant variate differentiated between teachers who remain and those who had resigned; this vairate was the time period they had worked in schools. Results from interviews showed that for teachers to continue to work in Islamic private schools, there is a need to change the welfare system of the school teachers and develop a clear and transparent system for their salary promotion. Also, teachers should have more opportunity to show their full potential. Teachers also recommended that to promote teachers' morale and motivate them to remain teaching in schools, Ministry of Education should reform rules or regulations of teacher recruiting as government employees. These newly-created rules and regulations should be clear and transparent. Consequently, both religious and ordinary course teachers have opportunity to be recruited equally. They believed that this change could affect the quality of teaching in the schools in positive way. In conclusion, the Thai government should support education in Islamic private schools seriously.
\end{abstract}

Keywords: teacher retention, Islamic private school, three southernmost provinces, Thailand, discriminant analysis

\section{Introduction}

Until now, the management of the education system in Thailand has been operated directly by the government, and they have a commitment to provide all people the best education that they can (Ministry of Education, 1999). However, the government lacks sufficient capacity to provide education to the public thoroughly. As a consequence the government allows the private sector to share and participate in the management of the national educational system. Government then changes duties of educational management by providing promotions and supports with several approaches such as academic issue, media equipment for learning, personnel issue, and financial issue (Office of the Private Education Commission, 2009, p. 2)

The three southernmost provinces of Thailand, including Pattani, Yala, and Narathiwat, are the Muslim majority areas which have their own culture, tradition, and language. Islam is the major religion in the area, and Islam influences people's lifestyle in every aspect, including education. Islam is a religion that gives priority to education. According to Islamic doctrine, every Muslim is required to acquire knowledge, both knowledge of the real world and knowledge of the religion. The prophet Muhammad said that "learning is a function necessary for Muslims both male and female". Besides knowledge learning, Islam also teaches the Muslim to disseminate the knowledge gained to other people (Trung-trongpairoj, Sama-un, Arer, Wae-useng, Yeunyong, Baka, \& Sukkee, 2006, p. 48)

The Islamic private school plays a very important part in providing education to youth in the southern border areas. The Thai Government has thus developed educational management in the three southern border provinces by subsidizing the budget in terms of student's headcount in the school. However, it is generally known that the 
private Islamic schools provide both religious and ordinary courses, but the government only supports the grant for students who are in the ordinary courses. Schools have to hire teachers to teach the religious courses. This results in a lack of financial support for teaching development in the private Islamic schools. Therefore, these schools have focused more on teaching the ordinary courses by recruiting well-educated teachers to teach subjects such as science, mathematics, foreign languages and Thai language, and schools have to encourage these teachers to remain with the school as long as possible.

Nevertheless, in the three southernmost provinces of Thailand, the private Islamic schools have experienced a high rate of teacher turnover, since there is an inequality of opportunities and career progression for private school teachers compared with public school teachers. In addition, well-educated and experienced teachers are not interested in working in private Islamic schools. They usually teach there for short-time periods. If there is a better chance for their career, such as better salary and position, they would prefer working in other places. The government has to periodically recruit teachers for working in this area. In addition, an insurgency in the three southern border provinces of Thailand is a factor that affects the teacher shortage problem within the area. For these reasons, there is a lack of well-educated teachers in the private Islamic schools which later affects the educational quality in the southern border provinces. This outcome has been supported by findings from the test of Basic Education at the national level (O-NET); the ranking test of students who are in Yala, Pattani, and Narathiwat provinces, is 74,75 , and 76 respectively. The average GPA of student in these three provinces is lower than the average GPA of students in other southern regions (Office of the Private Education Commission, 2009, pp. 10-11).

Teacher shortage has been a problem in private Islamic schools for years. Nowadays many schools have focused on encouraging well-educated staff to remain with the schools by providing more salary and welfare benefits. Although the compensations from private schools are not equal to those from public schools, it can give teachers a better quality of life. According to a research report from the Commission of National Education (Office of the National Education Commission, 1993, pp. 35-42), a factor which encourages teachers to remain in private schools is having a chance to succeed in life through improvement of knowledge by providing training courses or encouraging teachers to study for a Master's degree. Teachers have job security in the workplace, good welfare benefits, and good relationship with colleagues. Therefore, if the private Islamic schools, especially in the three southern border provinces, are to produce quality students, they have to focus on the teachers as well. The quality of students will depend on the teachers; if teachers enjoy stability in their work, they will have more spirit to teach students, and work with the schools as long as possible.

Therefore, this research investigates factors affecting the life of teachers who have taught both religious and ordinary courses in the private Islamic schools in three southernmost provinces in Thailand, and aims to create a model to distinguish teachers who remain teaching in the school and teachers who already resigned from the school.- Specifically, the objectives of this study are a) to investigate factors related to the life and well-being of teachers in the Islamic private schools in the three southernmost provinces in Thailand, and b) to generate guidelines for supporting teachers to work for the Islamic private school effectively, and having a longer period of teaching.

\section{Method}

\subsection{The Study Area/Target Group}

This was a mixed method research, conducted by the convergent parallel design approach. Due to the similarities of population and culture structure in the three southernmost provinces, this research applied cluster sampling to a random sample of teachers in Pattani province. Therefore, teachers in Pattani would represent teachers in the three southernmost provinces. The research sample was randomized from the list of teachers who both remained teaching in the private Islamic schools, and those who had already resigned from the schools. Total sample size was 246, divided into two groups: first, 31 teachers who remained teaching, and second, 115 teachers who had already resigned. Three teachers from each group were selected as key informants for interview. Fifteen school administrators from Yala, Pattanni and Narathiwat were also selected as key informants for in-depth interview.

\subsection{Data Collection}

The researcher sent questionnaires to participants by personal delivery and by mailing and collected after 15 days. For the qualitative approach, in-depth interviews were used. This was a follow-up interview about factors that affect to the life, well-being and possible resignation of teachers who taught in the private Islamic schools. In addition, the interview also sought recommendations for the schools in terms of recruiting, maintaining, and promoting teachers success in their career and life. Six teachers were selected from the two sample groups, (three from each), for such interviews also. 
The researcher conducted the interview by using the Cumulative Summarization Technique. The interview was conducted based on an interview guideline, and data was summarized and shared with the interviewees. Triangular validation was used to check the data's accuracy and validity, and then the summary was brought back to the interviewees again to check, before the conclusions in the research paper were finalized.

\subsection{Data Analysis}

For the quantitative research, data was analyzed in terms of descriptive statistics and discriminant analysis. For the qualitative research, the interview was the main approach, and content analysis and analysis induction were employed for analysis.

\section{Results}

\subsection{Contexts of the Private Islamic Schools in Pattani Province}

Examing the number of teachers by origin, 241 originated in the three southern border provinces area $(98.0$ percent), only 5 teachers originated from outside ( 2.0 percent). By educational level, 226 teachers graduated with Bachelor degree (91.9 percent), 12 teachers graduated with vocational degree (4.9 percent), and 8 teachers graduated with Master's degree (3.3 percent). By teaching qualification, 154 taught in the same subjects which they had graduated in (62.2 percent) and 92 teachers taught in different subjects (37.4 percent). 219 teachers had a teaching license ( 89.0 percent), and 27 did not (11.0 percent).

The average working time of teachers who remained teaching in the private Islamic schools was 11.5 years, and their average workload was 21.2 hours per week. The average working time of teachers who already resigned from the private Islamic school was 3.6 years, and their average workload was 22.2 hours per week. The support from schools in developing teaching skill, attitude towards the teaching profession, commitment towards the private Islamic school, was rated as medium for both groups of teachers. Fatigue from working was medium for the remain-school teachers and low for teachers who resigned.

\subsection{Results from Discriminant Analysis}

The analysis found that working time was the only variate which distinguished teachers who remained teaching in the schools and from those who had already resigned from schools. The results supported the hypothesis that at least 1 discriminant variate could predict the continuation or resignation of teachers in the private Islamic schools in in three southernmost provinces of Thailand significantly, as shown in Table 1.

Table 1. Test of significance for discriminant analysis

\begin{tabular}{lllllll}
\hline $\begin{array}{l}\text { Canonical Willks' } \\
\text { Function }\end{array}$ & Eigenvalue & Canonical Correlation & Wilks' Lambda & Chi-square & df & P-value \\
\hline 1 & 2.37 & .838 & .297 & 289.6 & 11 & .000 \\
\hline
\end{tabular}

Table 1 shows that there was only a single function with a P-value less than .05. Considering the Eigenvalue was 2.37 , this meant that there was a variate only used to classify both groups of teacher, statistically significant was at .05. But upon analysis by means of Roy's criterion, it was found that this discriminant variate could explain the grouping variance at 70.30 percent, a rather high value, with a group centroid of -0.544 for the resigned group and 1.436 for the teaching group. This indicated that, when discriminate analysis was applied, both groups were separated from each other obviously.

Considering the standardized discriminant coefficients of this variate, found that the most important discriminant variate that influenced the retention or resignation was following;

$$
\begin{gathered}
\text { Discriminant variate }=-.122\left(\mathrm{X}_{1}\right)+.021\left(\mathrm{X}_{2}\right)-.033\left(\mathrm{X}_{3}\right)+.107\left(\mathrm{X}_{4}\right)+1.024\left(\mathrm{X}_{5}\right)-.088\left(\mathrm{X}_{6}\right)-.268\left(\mathrm{X}_{7}\right)+.023\left(\mathrm{X}_{8}\right) \\
-.344\left(\mathrm{X}_{9}\right)+.227\left(\mathrm{X}_{10}\right)-.044\left(\mathrm{X}_{11}\right)
\end{gathered}
$$

where

$\mathrm{X}_{1}$ : was origin

$\mathrm{X}_{2}$ : was educational level

$\mathrm{X}_{3}$ : was teaching in the same subjects they have graduated

$\mathrm{X}_{4}$ : was teaching license

$\mathrm{X}_{5}$ : was working time 
$\mathrm{X}_{6}$ : was workload

$\mathrm{X}_{7}$ : was average income per month

$\mathrm{X}_{8}$ : were the supports by school to develop teaching skill

$\mathrm{X}_{9}$ : were attitudes towards the teaching profession

$\mathrm{X}_{10}$ : was commitment towards the school

$\mathrm{X}_{11}$ : was fatigue from working

Table 2. Loading matrix

\begin{tabular}{ll}
\hline Original variable & $\begin{array}{l}\text { Correlation coefficient } \\
\text { with Discriminant vaiate }\end{array}$ \\
\hline $\mathrm{X}_{5}:$ (working time) & $.909^{* * *}$ \\
$\mathrm{X}_{9}:$ (attitudes towards the teaching profession) & -.127 \\
$\mathrm{X}_{10}:$ (commitment towards the school) & .060 \\
$\mathrm{X}_{7}:$ (average income per month) & -.051 \\
$\mathrm{X}_{2}:$ (educational level) & .040 \\
$\mathrm{X}_{6}:$ (workload) & .036 \\
$\mathrm{X}_{11}:$ (tiredness from working) & .034 \\
$\mathrm{X}_{8}:$ (the supports by school to develop teaching skill) & -.027 \\
$\mathrm{X}_{3}:$ (teaching in the same subjects they have graduated) & .022 \\
$\mathrm{X}_{1}:$ (origin) & .013 \\
$\mathrm{X}_{4}:$ (teaching license) & -.006 \\
\hline$* * * \mathrm{P}<001$ &
\end{tabular}

The meaning of discriminant variate is inferred from the pattern of correlations between this variate and the original variable (X) (Tabachnick \& Fidell, 2001, p. 484) (see Table 2). Working time had a high correlation coefficient, at .909, statistically significant at .001 levels. However, the correlations between discriminant variate and the other original variables were not statistically significant. Thus this variable was named "factor of the working time" which was a factor that affected the existence of teachers in the private Islamic school. The model could predict the membership of teachers who remain teaching in the school correctly by 96.2 percent, and teachers who resigned from the school correctly by 99.1 percent. Considering the overview, the model could predict the membership of both groups of teacher correctly by 97.6 percent as shown in Table 3

Table 3. Classification matrix

\begin{tabular}{|c|c|c|c|}
\hline \multirow[b]{2}{*}{ Actual Group } & \multirow[b]{2}{*}{ Amount } & \multicolumn{2}{|l|}{ Predicted group } \\
\hline & & $\begin{array}{l}\text { Teacher group who } \\
\text { remains in the private } \\
\text { Islamic schools }\end{array}$ & $\begin{array}{l}\text { Teacher group who already } \\
\text { resigned from the private Islamic } \\
\text { schools }\end{array}$ \\
\hline $\begin{array}{l}\text { Teacher group who remains in the private } \\
\text { Islamic schools }\end{array}$ & 131 & $126(96.2 \%)$ & $5(3.8 \%)$ \\
\hline $\begin{array}{l}\text { Teacher group who already resigned from } \\
\text { the private Islamic schools }\end{array}$ & 115 & $1(0.9 \%)$ & $114(99.1 \%)$ \\
\hline ratio of the correct prediction & $97.6 \%$ & & \\
\hline
\end{tabular}

According to Table 3, the accuracy of prediction using the discriminant variate for teacers who remained teaching in schools was 96.2 percent while for teachers who had already resigned from school it was 99.1 percent. Therefore, this discriminant variate can predict status for teachers who already resigned slightly better than that for teachers who are still working at schools. Considering the overview, it was found that the discriminant variate could predict the memberships of both groups correctly by 97.6 percent overall. Therefore, it indicated that this variate produced the high efficiency of prediction. 


\subsection{Results from the Interviews}

Key informants of techers were divided into 2 groups, and 3 teachers were selected from each group. For school administrators, all 15 participants were interviewed individually. Factors that affected the existence and the resignation of teachers in the private Islamic school were,

a) Workload of teachers in the private Islamic school. Key informants suggested that workload was appropriate in teaching hours, working hours, and compensation received. If there were tasks other than teaching, school would decrease teaching hours for them. Some schools had staff who worked in general tasks. A minority of key informants suggested that there was too much workload. Teachers had to teach too many subjects, and taught in many level classes. It resulted in teachers having no time to prepare teaching instruction.

b) Attitudes towards the teaching profession; Key informants thought that higher living cost nowadays affected the teacher's life. Teachers had debts, so they had to spend money very carefully. In addition, key informants agreed that the unrest situations in southern area provided less impact to teachers. They also suggested that, in southern border area society, religious-teaching teachers would have more acceptance than teachers who taught the ordinary courses.

c) The support for self-development; key informants agreed that supports from the school were still limited. There were several training courses which were provided by external organizations, but not for every teacher.

d) The commitment towards the private Islamic school; key informants suggested that teachers agreed with the schools' goals. They would work the best for schools, and wanted to have close engagement with the schools. Some teachers resigned from the schools because they needed the advancement in their career.

e) Fatigue from working; most key informants felt tired sometimes due to work overload. They had to work with many tasks such teaching and administrative tasks.

There were recommendations for the private Islamic schools in recruiting, maintaining, and supporting teachers for success in their career and personal life. The recommendations took several forms. To recruit new staff, key informants suggested announcing the recruitment to the public. Some key informants suggested that the alumni should be considered first, and that recruitment should be operated by clear and fair division. In order to maintain teachers, fair compensations should be provided. The salary consideration system should be clear and fair. Administrators should focus more on teacher's work and life. For supporting teachers for success in career and life, schools should give more chances to teachers performing their best working skills. Furthermore, school administrators pointed that most schools could not afford enough funds to support teachers in both professional promotion and cost of living, so they should request more financial support from the Ministry of Education, especially for small schools. One school administrator suggested that the government provide professional promotion and financial support equally for both religious and common course teachers.

\section{Discussion}

According to the result of discriminant analysis, it was found that there is only one discriminant variate which can identify the continuation of teachers in the private Islamic school in three southernmost provinces and it was labeled as working time. The result supported the hypothesis that at least one discriminant variate could predict the existence and the resignation of teachers in the private Islamic school in three southernmost provinces significantly. This variate could explain the findings as follows. Working time is a variate which has the highest influence in the discriminant model. This is the most important variate which identifies the group of teacher who remain teaching in private Islamic schools and the group of teacher who resigned from them. In addition, it was found that working time affected the life and well-being of teachers in the private Islamic schools in three southernmost provinces also. The groups of teachers who have worked more than 10 years are more likely to remain in these schools than those who have worked below 10 years. This finding is supported by many studies which found that employee groups who are likely to resign the most are those who have worked for a short time such as less than a year (Weisman, 1982; Seybolt, 1986; Chantarakate, 2008). Therefore, all of these findings indicated that working time was related significantly to the resignation trend of teachers.

Based on responses from questionnaire and interviews, it can be concluded that there are four significant factors that can indicate teacher retention or resignation: workload, salaries and incentive, future career opportunity and support from school administrators.

According to research by Kersaint, Lewis, Potter, \& Meisels (2007), workload strongly affected teachers' decision to remain in schools. This finding is supported by Buchanan, Prescott, Schuck, Aubusson, Burke, \& Louviere (2013), Burk, Schuck, Aubusson, Buchanan, Louviere, \& Prescott (2013) and Veldman, Tartwijk, Brekelmans, \& Wubbels (2013) as well. Kersaint et al. (2007) pointed out that sometimes teachers had to do 
some extra work unrelated to teaching such as paper work. This caused teachers to do some kind of job they do not prefer. In addition, too much workload makes teachers spend less time with family and family responsibility are of greatest importance to teachers who have left the profession. Sabbagh \& Megbali (2008) also showed that high workload was the second-most important factor that caused teachers to resign from their jobs. Furthermore, Goodpaster, Adedokun, \& Weaver (2012) discovered that numerous responsibilities such as teaching courses to multiple level ability levels contributed to teacher attrition and cause them leave their profession too early, a study by Przygocki (2004) provided a similar result.

Salaries and incentive also play an important role for teachers staying or leaving. Sabbagh \& Megbali (2008) found that the most probable causes driving teachers to leave their jobs were insufficient or low salaries. The same results were also found in the other studies (Towse, Kent, Osaki, \& Kiruak, 2002; Kersaint et al., 2007). These results showed that teachers who left place gave a priority to financial responsibilities more than teachers who remained. Kersaint et al. (2007) showed that teachers who resigned may have found better paying position or positions with similar pay but less responsibility. This finding is consistent with many studies which found that low pay as a major source of dissatisfaction among teachers (Liu \& Meyer, 2005; Macdonald, 1995; Przygocki, 2004; Stinebrickner, 2001; Tye \& O’Brien, 2002). Towse et al. (2002) also pointed out that teaching was regarded as a low-paid job in Tanzania, therefore, it caused an acute shortage of suitably qualified teachers there.

Future career opportunity is one of the key factors that forces teachers to leave teaching career too early. This finding has been supported by Buchanan et al. (2013) who examined the factors that influence teachers' decisions about staying in or leaving the profession. They found that teachers who valued the opportunities they receive for professional learning remain at schools longer than the others. Similary, Towse et al. (2002) indicated that job and future aspiration help teachers remained teaching in school.

In addition, support from school administrators can be important for teacher retention. Burke et al. (2013) found that executive support such as any type of support provided by school executives (principal, deputy, head teacher, assistant principal) was a key factor to keep teachers at schools longer. Meanwhile, encouragement from administrators obviously affected teacher intention in rural schools (Malloy \& Allen, 2007). This finding is consistent with a large body of literature which indicates administrator support and care as a major source of retention or resignation among teachers (Buchanan et al., 2013; Kersaint et al., 2007; Veldman et al., 2013; Fetherson \& Lummis, 2012).

In conclusion, we draw some recommendations from this study. First, schools should provide appropriated compensations to teachers to build the motivation for working in the private Islamic schools. Second, schools should support activities to develop teacher's performance such as providing training courses, or supporting teachers to study higher degree to develop themselves and schools. Third, government agencies should focus more on private education, and find out the approach to promote private teachers as the government officers.

\section{Acknowledgements}

The research grant of Prince of Songkla Univerity, Pattani campus, Thailand for supporting this publication. Peter K. Smith (Emeritus Professor), Unit of School and Family Studies, Department of Psychology, Goldsmiths University of London who has advised on this article.

\section{References}

Buchanan, J., Prescott, A., Schuck, S., Aubusson, P., Burke, P., \& Louviere, J. (2013). Teacher retention and attrition: Views of early career teachers. Australian Journal of Teacher Education, 38(3), 112-129. http://dx.doi.org/10.14221/ajte.2013v38n3.9

Burke, P. F., Schuck, S., Aubusson, P., Buchanan, J., Louviere, J. J., \& Prescott, A. (2013). International of Educational Research, 62, 259-268. http://dx.doi.org/10.1016/j.ijer.2013.05.001

Chantarakate, M. (2008). Work values, organizational commitment, and locus of control and organizational citizenship behavior of Provincial Electricity Authority Head Office staffs. (Unpublished master thesis). Kasetsart University, Bangkok.

Fetherson, T., \& Lummis, G. (2012). Secondary teacher resignation in Western Australia: An anthology of existence. Australian Journal of Teacher Education, 37(4), 1-18.

Goodpaster, K. P. S., Adedokun, O. A., \& Weaver, G. C. (2012). Teachers' perceptions of rural STEM teaching: Implications for rural teacher retention. Rural Educator, 33(3), 9-22.

Kersaint, G., Lewis, J., Potter, R., \& Meisels, G. (2007). Why teachers leave: Factors that influence retention and 
resignation. Teaching and Teacher Education, 23, 775-794. http://dx.doi.org/10.1016/j.tate.2005.12.004

Liu, X. S., \& Meyer, J. P. (2005). Teachers' perceptions of their jobs: A multilevel analysis of the teachers' follow-up survey for 1994-1995. Teachers College Record, 107, 985-1003. http://dx.doi.org/10.1111/j.1467-9620.2005.00501.x

Macdonald, D. (1995). The role of proletarianization in physical education teacher attrition. Research Quarterly for Exercise and Sport, 66, 129-141. http://dx.doi.org/10.1080/02701367.1995.10762220

Malloy, W. W., \& Allen, T. (2007). Teacher retention in a teacher resiliency-building rural school. The Rural Educator, 28(2), 19-27.

Ministry of Education. (1999). Government Gazette-decree (Vol. 116, Sect. 74A). Bangkok: Express Transportation Organization of Thailand Publications.

Office of the National Education Commission. (1993). Factors affecting the success of private vocational schools. Bangkok: Kurusapa Printing Ladphrao.

Office of the Private Education Commission. (2009). Manual for school supporting (Vol. 1). Bangkok: Kurusapa Printing Ladphrao.

Przygocki, W. F. (2004). Teacher retention in Catholic schools. Catholic Education: A Journal of Inquiry and Practic, 7(4), 523-547.

Sabbagh, S. A., \& Megbali, A. A. (2008). Teacher retention problem in girl primary schools in Qatar. Retrieved from http://files.eric.ed.gov/fulltext/ED505916.pdf

Seybolt, J. W. (1986). Dealing with premature employer turnover. Journal of Nursing Administration, 16(3), 26-32.

Stinebrickner, T. R. (2001). A dynamic model of teacher labor supply. Journal of Labor Economics, 19,196-230. http://dx.doi.org/10.1086/209984

Tabachnick, B., \& Fidell, L. (2001). Using multivariate statistics (4th ed.). MA: Allyn \& Bacon.

Towse, P., Kent, D., Osaki, F., \& Kiruak, N. (2002). Non-graduate teacher recruitment and retention: Some factors affecting teacher effectiveness in Tanzania. Teaching and Teacher Education, 18, 637-652. http://dx.doi.org/10.1016/S0742-051X(02)00024-0

Trung-trongpairoj, S., Sama-un, B., Arer, S., Wae-useng, N., Yeunyong, N., Baka, M., \& Sukkee, C. (2006). Multicultural and educational development in three southern provinces: Case studies of pondok. Bangkok: Seaboon Publications.

Tye, B. B., \& O'Brien, L. (2002). Why are experienced teachers leaving the profession? Phi Delta Kappan, 84, 24-32.

Veldman, I., Tartwijk, J., Brekelmans, J., \& Wubbels, T. (2013). Job satisfaction and teacher-student relationships across the teaching career: Four case studies. Teaching and Teacher Education, 32, 55-65. http://dx.doi.org/10.1016/j.tate.2013.01.005

Weisman, C. S. (1982). Recruit for within: Hospital nurse retention in the 1980. Journal of Nursing Administration, 12(5), 24-31.

\section{Copyrights}

Copyright for this article is retained by the author(s), with first publication rights granted to the journal.

This is an open-access article distributed under the terms and conditions of the Creative Commons Attribution license (http://creativecommons.org/licenses/by/3.0/). 